\title{
Rapid Ischemic Cell Death in Immature Oligodendrocytes: A Fatal Glutamate Release Feedback Loop
}

\author{
Robert Fern and Thomas Möller \\ Department of Neurology, University of Washington, Seattle, Washington 98195
}

Ischemic injury of immature oligodendrocytes is a major component of the brain injury associated with cerebral palsy, the most common human birth disorder. We now report that cultured immature oligodendrocytes $\left[\mathrm{O}^{+} /\right.$galactoceramide $(\mathrm{GC})^{-}$] are exquisitely sensitive to ischemic injury ( $80 \%$ of cells were dead after 25.5 min of oxygen and glucose withdrawal). This rapid ischemic cell death was mediated by $\mathrm{Ca}^{2+}$ influx via non-NMDA glutamate receptors. The receptors were gated by the release of glutamate from the immature oligodendrocytes themselves via reverse glutamate transport and included a significant element of autologous feedback of glutamate from cells onto their own receptors. High $(\geq 100 \mu \mathrm{M})$ extracellular glutamate was protective against ischemic injury as a result of
non-NMDA glutamate receptor desensitization. Other potential pathways of $\mathrm{Ca}^{2+}$ influx, such as voltage-gated $\mathrm{Ca}^{2+}$ channels, NMDA receptors, or the $\mathrm{Na}^{+}-\mathrm{Ca}^{2+}$ exchanger, did not significantly contribute to ischemic $\mathrm{Ca}^{2+}$ influx or cell injury. Release of $\mathrm{Ca}^{2+}$ from intracellular stores was also not an important factor. In agreement with previous studies, more mature oligodendrocytes $\left(\mathrm{O}^{-} / \mathrm{GC}^{+}\right)$were found to be less sensitive to ischemic injury than were the immature cells studied here.

Key words: $\mathrm{Ca}^{2+}$; cell death; cerebral palsy; ischemia; glia; glutamate transport; neonatal brain injury; necrotic cell death; non-NMDA glutamate receptor; oligodendrocyte; white matter
Cerebral palsy is the most common human birth disorder, affecting between 1 and 2.5 per 1000 live births in the United States (Kuban and Leviton, 1994). The major pathology associated with cerebral palsy is an ischemic lesion most frequently located in the periventricular white matter and arising from a transient hypoxicischemic event in utero (Banker and Larroche, 1962; Paneth et al., 1994; Volpe, 1995). This lesion is termed "periventricular leukomalacia" and is characterized as an initial coagulating necrosis involving damage to axons and glia. Oligodendrocyte cell death is particularly marked, leading to hypomyelination (Flodmark et al., 1989; van de Bor et al., 1989; Rorke, 1992; Paneth et al., 1994; Volpe, 1995). It is the loss of axonal connections and myelination in these white matter structures that underlie the catastrophic motor deficits that characterize cerebral palsy (Volpe, 1995).

Typically, the fetal white matter structures that are subject to periventricular leukomalacia are undergoing myelinogenesis (Rice et al., 1981; Leviton and Paneth, 1990; Kinney and Back, 1999). The oligodendrocytes involved in the injury are primarily at an immature developmental stage characterized by the presence of surface markers such as $\mathrm{A}_{2} \mathrm{~B}_{5}$ and $\mathrm{O} 4$ and the absence of galactoceramide (GC) and myelin basic protein (MBP) (Hardy and Reynolds, 1991; Rivkin et al., 1995; Miller, 1996; Back et al., 1998; Kinney and Back, 1999). Although immature oligodendrocytes $\left(\mathrm{O}^{+} / \mathrm{MBP}^{-}\right)$are more vulnerable than mature oligodendrocytes $\left(\mathrm{O}^{-} / \mathrm{MBP}^{+}\right)$to oxidative stress (Back et al., 1998), their sensitivity to ischemic injury is not known. Mature oligodendrocytes $\left(\mathrm{GC}^{+}\right)$exposed to 60-120 min of ischemia exhibit

Received June 28, 1999; revised Sept. 27, 1999; accepted Oct. 8, 1999.

This work was supported by the National Institute of Neurological Disorders and Stroke Grant NS36790 to R.F. Thanks to Bruce R. Ransom for use of facilities and Mark Moksycki for technical assistance.

Correspondence should be addressed to Dr. Robert Fern, Department of Neurology, University of Washington, Box 356465, Seattle, WA 98195. E-mail address: bobfern@u.washington.edu.

Copyright () 1999 Society for Neuroscience $0270-6474 / 99 / 200034-09 \$ 15.00 / 0$ cell death determined $24 \mathrm{hr}$ later via a mechanism involving $\mathrm{Ca}^{2+}$-permeable non-NMDA glutamate receptors (McDonald et al., 1998). This pathway can also be activated in immature and mature oligodendrocytes by exposure to non-NMDA glutamate receptor agonists, where cell death has been reported over a 1-24 hr time course (Yoshioka et al., 1996; Matute et al., 1997; Matute, 1998; McDonald et al., 1998). The acute affects ( $<60 \mathrm{~min})$ of ischemia or non-NMDA glutamate receptor agonists on cell viability were not studied in these previous investigations.

In the present study we examine the effects of ischemia (oxygen and glucose withdrawal) on intracellular $\mathrm{Ca}^{2+}\left(\left[\mathrm{Ca}^{2+}\right]_{\mathrm{i}}\right)$ and cell viability in immature oligodendrocytes $\left(\mathrm{O}^{+} / \mathrm{GC}^{-}\right)$. Ischemic cell death was found to be extremely rapid (mean latency to cell death was $20.4 \mathrm{~min}$ ) and occurred after $\mathrm{Ca}^{2+}$ influx mediated by non-NMDA glutamate receptors. Activation of glutamate receptors followed glutamate release from oligodendrocytes, including an element of autologous feedback in which glutamate released from a cell acted on that cell's own receptors. More mature oligodendroyctes $\left(\mathrm{A}_{2} \mathrm{~B}_{5}{ }^{-} / \mathrm{GC}^{+}\right)$were more tolerant of ischemia, suggesting that this mechanism of oligodendrocyte injury is particularly relevant to the fetal brain. These findings show immature oligodendrocytes to be more sensitive to ischemia than thought previously. Indeed these cells are more sensitive to ischemic injury than any CNS cell type examined previously, including neurons (Petito and Pulsinelli, 1984; Goldberg and Choi, 1993; Johnson et al., 1994; Pantoni et al., 1996; Kusumoto et al., 1997; Lyons and Kettenmann, 1998; Petito et al., 1998).

\section{MATERIALS AND METHODS}

Cell culture. Oligodendrocytes were obtained according to the method of McCarthy and de Vellis (1980). In brief, newborn Long-Evans rat pups [postnatal day $0(\mathrm{P} 0)-\mathrm{P} 2$ ] were anesthetized by $\mathrm{CO}_{2}$ inhalation and decapitated, the cerebral cortexes were dissected out, and the meninges were removed. The cortexes were cut into $1 \mathrm{~mm}^{3}$ pieces and placed in DMEM/F12 (1:1; which contains $4500 \mathrm{mg} / 1 \mathrm{~L}$-glutamine) without FBS 
and enzymatically treated for 30 min with papain $(20 \mathrm{U} / \mathrm{ml})$ before trituration and plating in poly-L-lysine-coated cell culture flasks. The medium was changed $<24 \mathrm{hr}$ after plating to eliminate debris and bacteria. Cells were maintained in DMEM/F12 medium supplemented with $10 \%$ FBS and kept at $37^{\circ} \mathrm{C}$ in an atmosphere of $5 \% \mathrm{CO}_{2}$ and $95 \%$ humid air. The medium was changed every $3-4 \mathrm{~d}$.

For plating on coverslips, immature oligodendrocytes were collected as follows between 10 and $15 \mathrm{~d}$ of primary culture. Coculture flasks were shaken with mild-to-moderate force to remove any adherent microglia, and the cultures were washed twice with media. The flask was then shaken with moderate force to remove oligodendrocytes from the astrocyte layer, and the supernatant was collected and centrif uged at $900 \mathrm{rpm}$ for $10 \mathrm{~min}$. The pellet was resuspended in DMEM/F12 with $10 \%$ FBS, and the cells were plated on $22 \times 44 \mathrm{~mm}$ poly-L-lysine-coated glass coverslips. After 20-30 min, the coverslips were washed with PBS and kept in a cell culture incubator in Sato medium with 5\% horse serum overnight for use the next day. For experiments on more mature cells, primary cultures were maintained for $30-60 \mathrm{~d}$ as described above, and cells were plated onto poly-L-lysine- and laminin-coated $22 \times 44 \mathrm{~mm}$ glass coverslips.

Immunocytochemistry. Cell cultures were washed in PBS containing $1 \%$ normal sheep serum (NSS). Cells were then fixed with $4 \%$ paraformaldehyde (PFA) for 10 min before washing three times in PBS with $1 \%$ NSS for 5 min each before a 60 min incubation in 4\% NSS in PBS and primary antibody (anti- $\mathrm{A}_{2} \mathrm{~B}_{5},-\mathrm{O} 4,-\mathrm{GC}$, or -GFAP; Boehringer Mannheim, Indianapolis, IN). In the case of anti-GFAP, a 30 min permeabilization step with $0.5 \%$ Triton $\mathrm{X}-100$ was conducted before incubation with primary antibody, and $0.5 \%$ Triton X-100 was included in antibody incubation steps. Cells were then washed three times in PBS with $1 \%$ NSS for 5 min each before a 60 min incubation in PBS with 1\% NSS containing indocarbocyanine (Cy3)-conjugated secondary antibody (Fab fragment; Sigma, St. Louis, MO). Cells were again washed three times in PBS, and the coverslips were mounted in Mowiol medium. Coverslips were visualized with phase-contrast optics, and $\mathrm{Cy} 3$ staining was detected by illumination at $550 \mathrm{~nm}$ and a rhodamine filter set. Phasecontrast images were collected with a stills camera, and fluorescent images were collected with the digital camera attached to the imaging setup.

Imaging. Coverslips were placed in artificial CSF (aCSF) comprised of (in $\mathrm{mM}$ ): $\mathrm{Na}^{+}, 153 ; \mathrm{K}^{+}, 3 ; \mathrm{Mg}^{2+}, 2 ; \mathrm{Ca}^{2+}, 2 ; \mathrm{Cl}^{-}, 131 ; \mathrm{HCO}_{3}^{-}, 26$; $\mathrm{H}_{2} \mathrm{PO}_{4}^{-}, 2$; and glucose, 10 . A stock solution containing $1 \mathrm{~mm}$ fura-2 AM (Molecular Probes, Eugene, OR) was made in dry DMSO and $10 \%$ pluronic acid. A final concentration of $5 \mu \mathrm{M}$ fura-2 AM was used for all incubations. Coverslips were incubated in aCSF gassed with hydrated $95 \% \mathrm{O}_{2}$ and $5 \% \mathrm{CO}_{2}$ for $30-40 \mathrm{~min}$ at room temperature before being washed in aCSF and mounted in the perfusion chamber.

Coverslips were sealed onto a Plexiglas perfusion chamber (atmosphere chamber; Warner Instruments, Hamden, CT) with silicone grease. aCSF was run through the chamber at a rate of $2-3 \mathrm{ml} / \mathrm{min}$ with a fluid level of $\sim 1 \mathrm{~mm}$. The top of the chamber was sealed with a second coverslip, and $95 \% \mathrm{O}_{2}$ and $5 \% \mathrm{CO}_{2}$ were blown over the aCSF at a rate of $1.5 \mathrm{l} / \mathrm{min}$. The chamber is described in greater detail in Fern (1998). aCSF was bubbled with $95 \% \mathrm{O}_{2}$ and $5 \% \mathrm{CO}_{2}$, kept in a water bath at $\sim 40^{\circ} \mathrm{C}$, and run through Tygon plastic tubing (Norton, $\mathrm{OH}$ ) that was copper clad to minimize gas exchange. A star valve with a purge system was used to achieve a bath dye washout of $\sim 1 \min$ (Fern, 1998).

The chamber was mounted on the stage of a Nikon diaphot-TMDinverted epifluorescence microscope (Tokyo, Japan) equipped with a $20 \times$ air objective (Olympus Optical, Tokyo, Japan). Chamber temperature was closely maintained at $37^{\circ} \mathrm{C}$ using a flow-through feedback tubing heater (Warner Instruments) positioned immediately before the aCSF entered the chamber and a feedback stage heater (Warner Instruments), which heated the metal surround holding the chamber. This combination of heaters regulated the temperature of the bath and coverslip to $37^{\circ} \mathrm{C}$ as established periodically with a temperature probe.

Cells were visualized with a Hamamatsu C2400 ICCD video camera and image intensifier system (Hamamatsu, Bridgewater, NJ). Data were collected and stored with an image acquisition program from Photon Technology International (East Brunswick, NJ) running on a Dell 486Omniplex personal computer (Austin, TX). Data were converted to TIF format after the experiment and transferred to a Macintosh Power personal computer for off-line analysis using NIH IMAGE (National Institutes of Health, Bethesda, MD).

Experimental protocol. After being mounted in the microscope, cells were allowed to equilibrate for $20 \mathrm{~min}$. A $5 \mathrm{~min}$ period of baseline was then taken before switching to ischemic conditions. Ischemia was induced by changing from aCSF to perfusion with zero-glucose aCSF that had been bubbled with $95 \% \mathrm{~N}_{2}$ and $5 \% \mathrm{CO}_{2}$ for a least an hour. The atmosphere in the recording chamber was simultaneously switched to $95 \% \mathrm{~N}_{2}$ and $5 \% \mathrm{CO}_{2}$. Ischemia was maintained for $55 \mathrm{~min}$. Cells were initially brought into focus during illumination at $360 \mathrm{~nm}$. A field of $15-100$ cells was typical and was randomly selected from the central area of the coverslip. One field was used per coverslip, and a minimum of three coverslips was tested for each experimental protocol. Cells were then illuminated at 340,360 , and $380 \mathrm{~nm}$, and images were collected at $520 \mathrm{~nm}$. This series was collected every minute, with 8-16 frames averaged per excitation wavelength. Changes in the 340/380 ratio were taken to indicate changes in $\left[\mathrm{Ca}^{2+}\right]_{i}($ Grynkiewicz et al., 1985). Because the majority of cells died during ischemia, it was not possible to calibrate the ratio signal to give accurate values of $\left[\mathrm{Ca}^{2+}\right]_{\mathrm{i}}$.

Cell death. The 360 signal was monitored to assess the capacity of cells to retain dye. The isosbestic $\left(\mathrm{Ca}^{2+}\right.$-insensitive) wavelength was used to eliminate the possibility that signal changes were caused by alterations in $\left[\mathrm{Ca}^{2+}\right]_{\mathrm{i}}$. Sudden and irreversible loss of the 360 signal from a cell such that the fluorescence fell to the background level correlated with the breakdown of cell membrane integrity and release of dye into the extracellular space (Lemasters et al., 1987; Geeraerts et al., 1991; Fern, 1998). Loss of cell membrane integrity was taken to indicate cell death. The use of intracellular fluorescent dye for quantitating cell death has been described in detail (Bevensee et al., 1995), and fura-2 has been used in this way in previous studies (Johnson et al., 1994; Fern, 1998).

Statistics. Results are reported as means \pm SEM. Means represent values of all cells studied under a particular condition (cells from all coverslips pooled). Statistical significance was determined by ANOVA with Tukey post-test.

\section{RESULTS}

Under phase contrast, cells had either a spherical or bipolar morphology or exhibited a spherical cell body that extended several short processes (Fig. 1 $A, C$ ). Immunostaining for the surface marker $\mathrm{O} 4$ (Fig. $1 A, B$ ) revealed that almost all cells were positive for this indicator of immature oligodendrocytes (Sommer and Schachner, 1981), a marker widely expressed by immature oligodendrocytes in the midgestation human fetus, the period most commonly subject to periventricular leukomalacia (Kinney and Back, 1999). A large majority of cells also stained positive for the marker of oligodendrocyte precursors $\mathrm{A}_{2} \mathrm{~B}_{5}$ (Fig. 1C,D). This coexpression of $\mathrm{O} 4$ and $\mathrm{A}_{2} \mathrm{~B}_{5}$ is similar to that reported previously in immature oligodendrocytes (Kinney and Back, 1999). A very small number of $\mathrm{GC}^{+}$cells were observed, and no $\mathrm{GFAP}^{+}$ astrocytes were found (data not shown).

\section{Ischemic $\mathrm{Ca}^{2+}$ influx and cell death}

$\left[\mathrm{Ca}^{2+}\right]_{\mathrm{i}}$ (340/380 ratio) (Grynkiewicz et al., 1985) increased rapidly after the initiation of ischemia (Fig. $1 E$ ). $\left[\mathrm{Ca}^{2+}\right]_{i}$ started to rise within the first minute of ischemia and typically continued to increase for the first $5-10 \mathrm{~min}$. $\left[\mathrm{Ca}^{2+}\right]_{i}$ was relatively stable in cells perfused for $60 \mathrm{~min}$ with aCSF, and the 360 intensity of these cells drifted monotonically (Fig. $1 G$ ). During ischemia, the 360 intensity of cells collapsed at some point, indicating the lose of cell membrane integrity (Fig. $1 E$, arrow, cell death). Cells started to lose membrane integrity within the first few minutes of ischemia, with a mean time to cell death of $20.4 \mathrm{~min}$ (Fig. $1 \mathrm{H}$, shaded histogram, left $y$-axis). In cells that survived ischemia for $>10-15 \mathrm{~min},\left[\mathrm{Ca}^{2+}\right]_{\mathrm{i}}$ tended to plateau at that point (data not shown). In the absence of extracellular $\mathrm{Ca}^{2+}$ (perfusion with zero $\mathrm{Ca}^{2+}$ and $50 \mu \mathrm{M}$ EGTA), ischemia typically produced only an initial transient rise in $\left[\mathrm{Ca}^{2+}\right]_{\mathrm{i}}$ that was not associated with cell death (Fig. $1 F$ ). The cumulative rate of cell death during ischemia $(n=396)$ and during ischemia in the absence if extracellular $\mathrm{Ca}^{2+}(n=211)$ is shown in Figure $1 H$ (solid lines, right $y$-axis). 
Figure 1. Changes in $\left[\mathrm{Ca}^{2+}\right]_{\mathrm{i}}$ and cell death during ischemia in immature oligodendrocytes. $A, C$, Typical morphology of immature oligodendrocytes (phase contrast) is shown. $B$, O4 staining of the cells shown in $A$ is presented. $D, \mathrm{~A}_{2} \mathrm{~B}_{5}$ staining of the cells shown in $C$ is presented. Note that the cells were typically both $\mathrm{O}_{4}^{+}$and $\mathrm{A}_{2} \mathrm{~B}_{5}{ }^{+}$. E, The onset of ischemia $\left(\mathrm{O}_{2}\right.$ and glucose withdrawal; treatment indicated by solid horizontal bar) was rapidly followed by an increase in the $340 / 380$ ratio in fura-2loaded immature oligodendrocytes (top data points, filled circles), corresponding to an increase in $\left[\mathrm{Ca}^{2+}\right]_{\mathrm{i}}$ (Grynkiewicz et al., 1985). The 360 intensity of this cell (bottom data points, filled squares) was stable over the first part of ischemia but collapsed to baseline after $19 \mathrm{~min}$ of ischemia (arrow, indicating cell death at that point). $F$, Ischemia in the absence of extracellular $\mathrm{Ca}^{2+}$ (perfusion with 0 $\mathrm{mM} \mathrm{Ca}{ }^{2+}$ and $50 \mu \mathrm{M}$ EGTA) resulted in a small transient increase in $\left[\mathrm{Ca}^{2+}\right]_{\mathrm{i}}$ that was not associated with cell death. $G$, $\left[\mathrm{Ca}^{2+}\right]_{\mathrm{i}}$ and 360 intensity were relatively stable in cells during $60 \mathrm{~min}$ of perfusion with normal aCSF (no ischemia). $H$, The distribution of cell death in 396 cells exposed to ischemia is plotted as a histogram (left $y$-axis; shaded vertical bars), demonstrating that cell death reached a peak after $10-15$ min of ischemia. The cumulative percentage of cell death during ischemia is plotted on the right $y$-axis (solid lines) for normal $(2 \mathrm{~mm}$ $\mathrm{Ca}^{2+}$ ) and zero $\mathrm{Ca}^{2+}$ conditions.
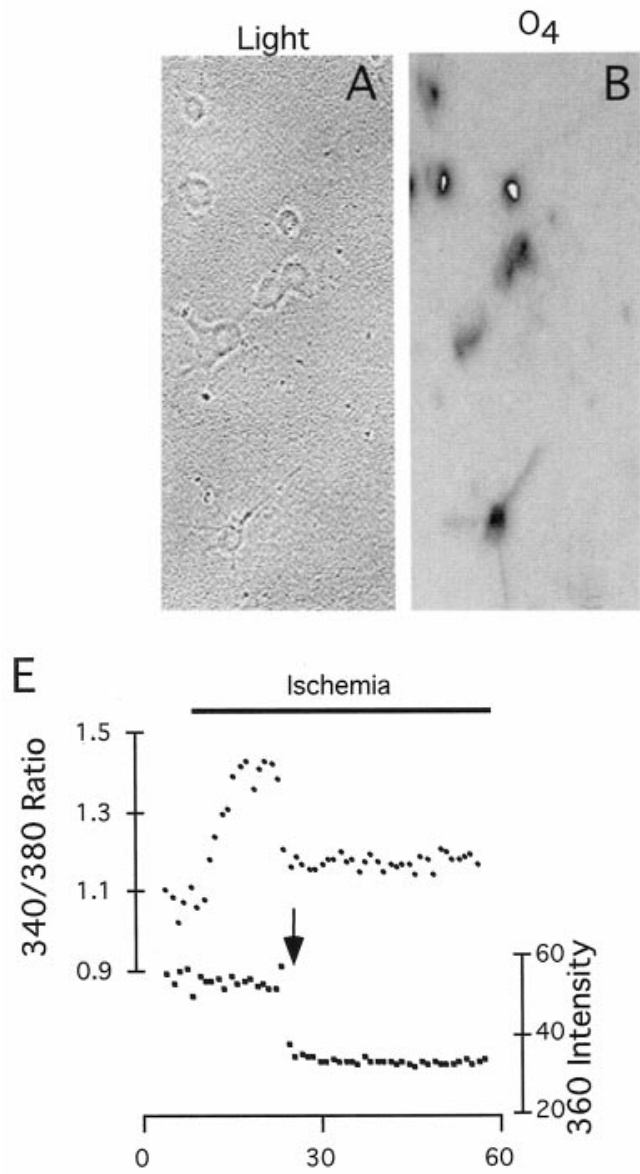

G

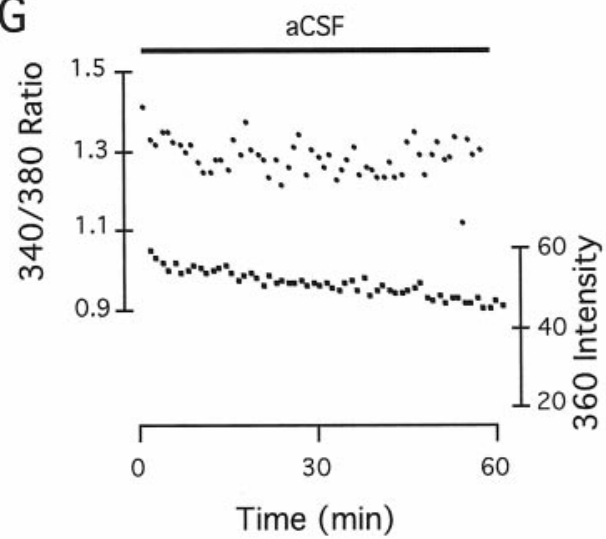

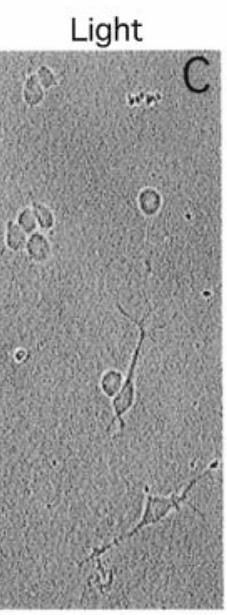

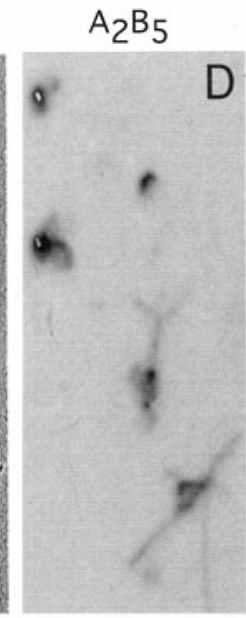

$\mathrm{F}$

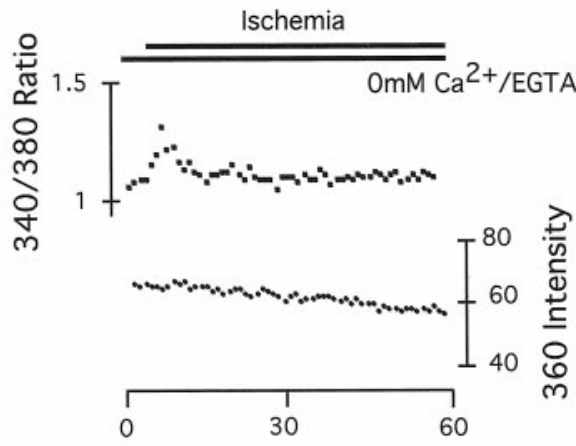

Time ( $\min )$

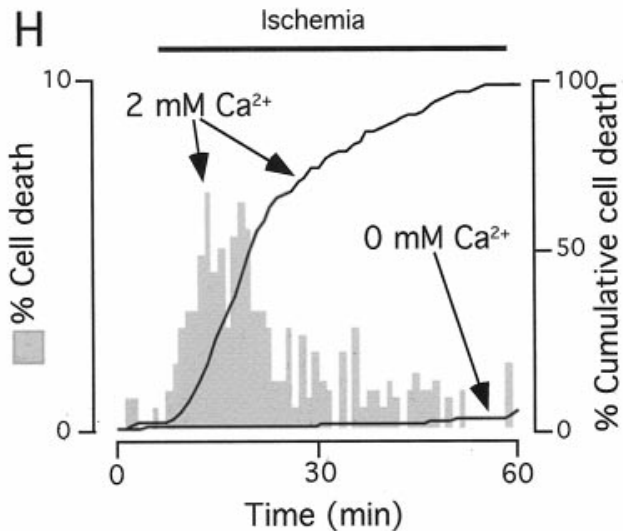

\section{Route of $\mathrm{Ca}^{2+}$ influx}

Perfusion with $30 \mu \mathrm{M}$ CNQX (a non-NMDA glutamate receptor antagonist) abolished the rises in $\left[\mathrm{Ca}^{2+}\right]_{\mathrm{i}}$ produced by ischemia in most cells (Fig. 2A), although small rises were sometimes observed (data not shown). If the application of $30 \mu \mathrm{M}$ CNQX was delayed until $10 \mathrm{~min}$ after the onset of ischemia, $\left[\mathrm{Ca}^{2+}\right]_{\mathrm{i}}$ typically started to decline at that point toward baseline (Fig. $2 B$ ). The extent of cell death during ischemia was much reduced by 30 $\mu \mathrm{M}$ CNQX, including the $10 \mathrm{~min}$-delayed application protocol (Fig. 2C). The NMDA receptor antagonist MK-801 had no similar effect on the extent of ischemic cell death (Fig. $2 C$ ) or on the changes in $\left[\mathrm{Ca}^{2+}\right]_{\mathrm{i}}$ typically seen during ischemia (Fig. 2D). Perfusion with the broad-spectrum voltage-gated $\mathrm{Ca}^{2+}$ blocker $\mathrm{La}^{3+}(100 \mu \mathrm{M})$ or the $\mathrm{Na}^{+}-\mathrm{Ca}^{2+}$ exchange inhibitor bepridil
$(100 \mu \mathrm{M})$ was also without effect (Fig. 2E,F). The effects of perfusion with various solutions on the extent of cell death and the mean time to cell death are shown in Figure 3, confirming that only removing extracellular $\mathrm{Ca}^{2+}$ or blocking non-NMDA receptors had a significant impact on these parameters.

Glutamate excitotoxicity in neurons is mediated both by $\mathrm{Ca}^{2+}$ influx and by cell swelling (Goldberg and Choi, 1993). Cytotoxic cell swelling can be prevented in neurons by replacing extracellular $\mathrm{Na}^{+}$with an impermeant ion such as choline (Goldberg and Choi, 1993). Perfusion with aCSF containing $5 \mathrm{~mm} \mathrm{Na}^{+}$(compared with $128 \mathrm{~mm} \mathrm{Na}^{+}$in normal aCSF, the difference replaced with choline) did not affect either $\mathrm{Ca}^{2+}$ influx or the extent of cell death during ischemia (Fig. 4A), suggesting that $\mathrm{Na}^{+}$-dependent cell swelling is not an important factor in ischemic injury of 
A

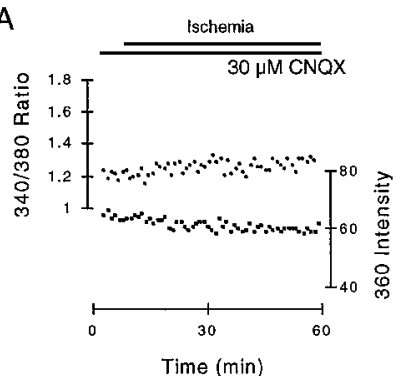

$\mathrm{C}$
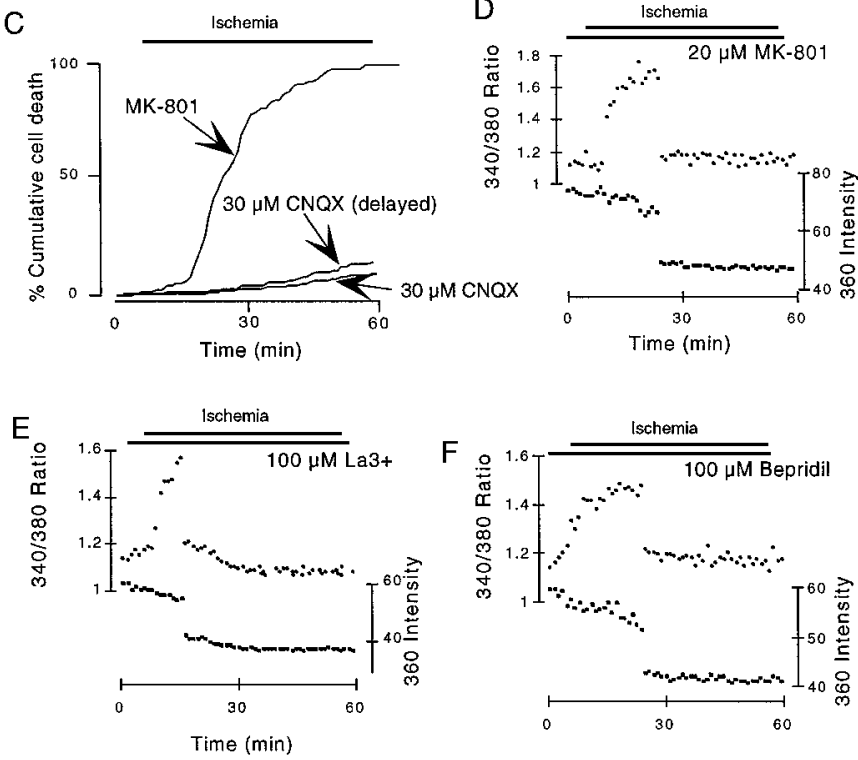

Figure 2. $\mathrm{Ca}^{2+}$ influx and cell death were mediated exclusively by non-NMDA receptors. $A$, In the presence of $30 \mu \mathrm{M} \mathrm{CNQX}$, ischemia did not produce a significant increase in $\left[\mathrm{Ca}^{2+}\right]_{i}$ in this cell, and cell membrane integrity remained intact. $B$, Delayed application of CNQX (10 min after the onset of ischemia) resulted in a fall in $\left[\mathrm{Ca}^{2+}\right]_{\mathrm{i}}$ toward baseline. $C$, The cumulative rate of ischemic cell death in the presence of $30 \mu \mathrm{M}$ CNQX, after the delayed application of $30 \mu \mathrm{M}$ CNQX, and in the presence of $20 \mu \mathrm{M}$ MK-801 is shown. Note that delayed application of CNQX was almost as protective as continual CNQX perfusion. $D-F$, Perfusion with the NMDA receptor antagonist MK-801 $(D)$, the broadspectrum voltage-gated $\mathrm{Ca}^{2+}$ channel blocker $\mathrm{La}^{3+}(100 \mu \mathrm{M} ; E)$, or the $\mathrm{Na}^{+}-\mathrm{Ca}^{2+}$ exchange inhibitor bepridil $(100 \mu \mathrm{M} ; F)$ did not block ischemic $\mathrm{Ca}^{2+}$ influx or cell death.

neonatal oligodendrocytes. Similar data were found with $28 \mathrm{~mm}$ $\mathrm{Na}^{+}$aCSF (data not shown). Zero $\mathrm{Na}^{+}$solutions were found to lead to cell detachment and were not used. Block of voltage-gated $\mathrm{Na}^{+}$channels on the cells with $200 \mathrm{~nm}$ TTX also had no effect on $\mathrm{Ca}^{2+}$ influx or cell death during ischemia (Fig. 4B).

\section{Extracellular glutamate: role of receptor desensitization}

The effects of exposure to glutamate were investigated under normoxic-normoglycemic conditions. Perfusion with $1 \mathrm{~mm}$ glutamate either produced no effect on $\left[\mathrm{Ca}^{2+}\right]_{\mathrm{i}}$ or evoked a partly transient increase (Fig. $5 A$, bottom, top data points, respectively). In a small number of cells, $1 \mathrm{~mm}$ glutamate evoked $\left[\mathrm{Ca}^{2+}\right]_{\mathrm{i}}$ oscillations (data not shown). Application of $1 \mathrm{~mm}$ glutamate for 55 min resulted in no significant increase in the occurrence of cell death compared with perfusion with aCSF [Fig. $5 D, 2.3 \pm 0.2 \%$ $(n=210)$ compared with $1.4 \pm 0.5 \%(n=211)$, respectively; $p>$ $0.5]$. Perfusion with the non-NMDA glutamate receptor desen- sitization blocker cyclothiazide $(100 \mu \mathrm{M})$ resulted in large and sustained increases in $\left[\mathrm{Ca}^{2+}\right]_{\mathrm{i}}$ during perfusion with $1 \mathrm{~mm}$ glutamate (Fig. 5B), which could be associated with cell death (Fig. $5 C$ ). The extent of cell death during perfusion with $1 \mathrm{~mm}$ glutamate in the presence of $100 \mu \mathrm{M}$ cyclothiazide was significantly greater than that during perfusion with aCSF [Fig. 5D, $15.5 \pm$ $3.4 \%(n=172)$ compared with $1.4 \pm 0.5 \%(n=211)$, respectively; $* * * p<0.001]$.

In the presence of $1 \mathrm{~mm}$ glutamate, ischemia resulted in either a small rise in $\left[\mathrm{Ca}^{2+}\right]_{\mathrm{i}}$ or no detectable rise (Fig. $6 \mathrm{~A}$, bottom data points). Glutamate $(1 \mathrm{~mm})$ was highly protective against ischemic cell death, reducing the extent of cell death to $24.5 \pm 0.4 \%$ (Fig. $6 B ; n=163)$, significantly lower than that in control ischemia (Fig. $\left.6 B,{ }^{* * *} p<0.001\right)$. In the presence of cyclothiazide $(100 \mu \mathrm{M})$ the protective effect of $1 \mathrm{~mm}$ glutamate was significantly reduced, with $35.9 \pm 1.2 \%$ of cells dying during ischemia (Fig. $6 B ; n=145$; *** $p<0.001$ compared with ischemic cell death in $1 \mathrm{~mm}$ glutamate alone). Large increases in $\left[\mathrm{Ca}^{2+}\right]_{i}$ were observed during ischemia in the combined presence of $100 \mu \mathrm{M}$ cyclothiazide and $1 \mathrm{~mm}$ glutamate (Fig. $6 A$, top data points). As would be predicted if the protective action of glutamate were caused by receptor desensitization, the effect was concentration dependent. Glutamate concentrations between $100 \mathrm{~nm}$ and $25 \mu \mathrm{M}$ did not influence either the mean time to ischemic cell death or the proportion of cells that died during ischemia compared with control ischemia (Fig. 6C,D).

\section{Glutamate release from oligodendrocytes}

In an effort to reduce extracellular glutamate concentration, we perfused the cells with a pyruvate and glutamic-pyruvic transaminase (GPT) glutamate-scavanging system. In the presence of pyruvate, GPT will catalyze the conversion of glutamate to alanine and a-ketoglutarate, reducing the glutamate concentration (O’Brien and Fischbach, 1986; Min et al., 1998). Increases in $\left[\mathrm{Ca}^{2+}\right]_{\mathrm{i}}$ during ischemia in the presence of $20 \mathrm{U} / \mathrm{ml}$ GPT and 2 $\mathrm{mm}$ pyruvate were generally smaller than those seen in the presence of pyruvate alone (Fig. 7A,B). The glutamate-scavenging system reduced the extent of cell death during $55 \mathrm{~min}$ of ischemia to $65.5 \pm 9.9 \%(n=246)$, significantly lower than that found during ischemia in the presence of pyruvate alone (Fig. $7 C$, $\left.86.6 \pm 5.3 \% ; n=255 ; *^{* *} p<0.001\right)$. Large increases in $\left[\mathrm{Ca}^{2+}\right]_{\mathrm{i}}$ were found in immature oligodendrocytes during ischemia in the presence of $2 \mathrm{~mm}$ pyruvate alone (Fig. $7 B$ ), and the extent of cell death during ischemia was not significantly different from that found during control ischemia (Fig. $7 C, 86.7 \pm 5.3 \%$; $n=255$; $p>0.5)$.

The glutamate transport inhibitor dihydrokainic acid (DKA) is membrane permeant and has been identified as an inhibitor of glutamate release via reverse transport (Seki et al., 1999). Perfusion with $100 \mu \mathrm{M}$ DKA significantly extended the mean time to ischemic cell death compared with control (Fig. $7 E, 39.4 \pm 0.5$ $\min ; n=327 ; p<0.001)$. The ischemic cell death found in the presence of DKA was associated with significant increases in $\left[\mathrm{Ca}^{2+}\right]_{\mathrm{i}}$ (Fig. 7D).

To test the hypothesis that glutamate released from a cell may act on glutamate receptors on the same cell, oligodendrocyte cultures of very low cell density were produced. The cell culture protocol was similar to that used for normal density cultures, with the exception that only a small number of cells from primary culture were plated onto the coverslips. Coverslips were used between 4 and $24 \mathrm{hr}$ after plating. After the coverslips were 
Figure 3. Data summary. The proportion of cells that die within a $55 \mathrm{~min}$ period of ischemia (right $y$-axis; gray bars) and the mean time to cell death (left $y$-axis; black bars) under various conditions. The extent of cell death produced by ischemia was significantly reduced by perfusion with CNQX or 0 $\mathrm{mm} \mathrm{Ca}{ }^{2+}$ but not by other conditions. Only perfusion with CNQX or $0 \mathrm{~mm}$ $\mathrm{Ca}^{2+}$ extended the mean time to cell death. $* * *=p<0.001$ compared with ischemia.

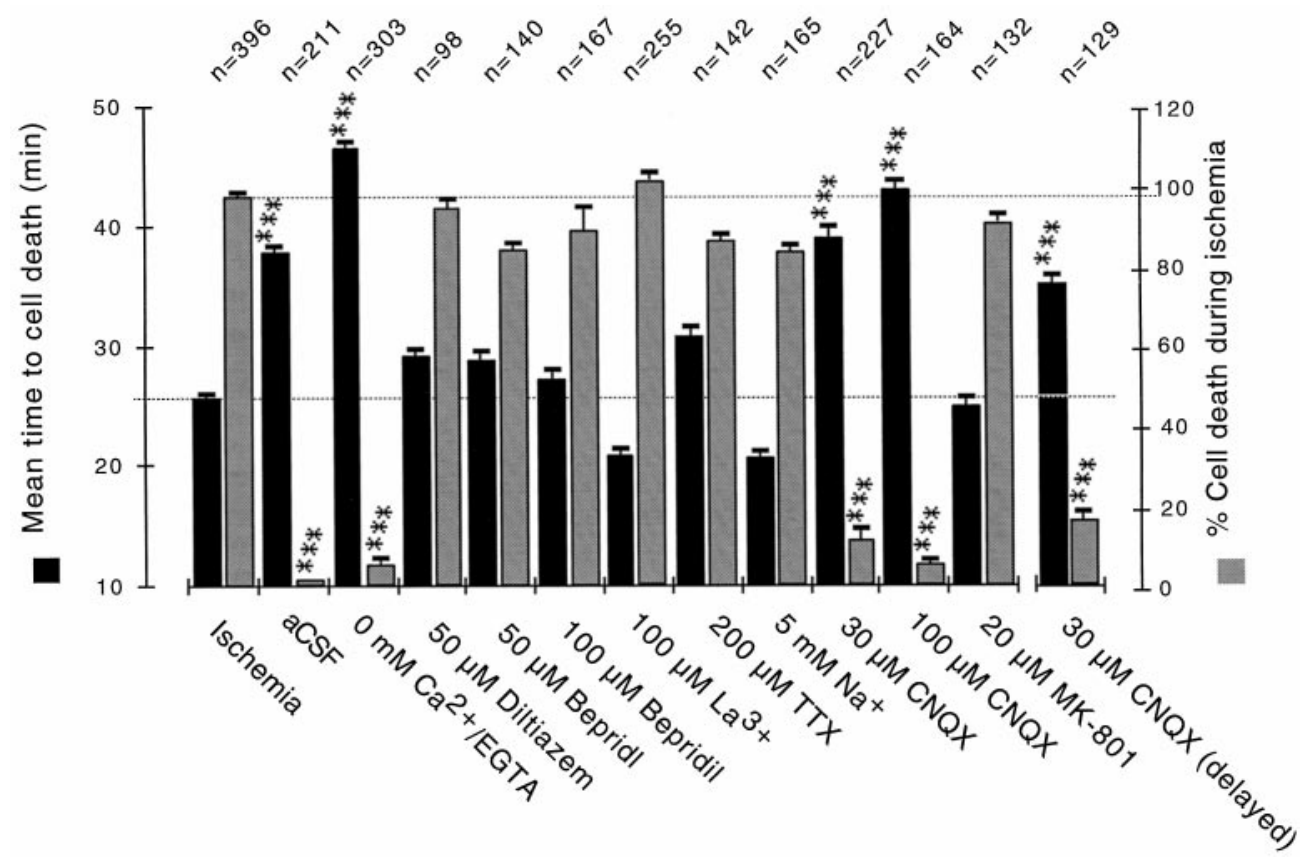


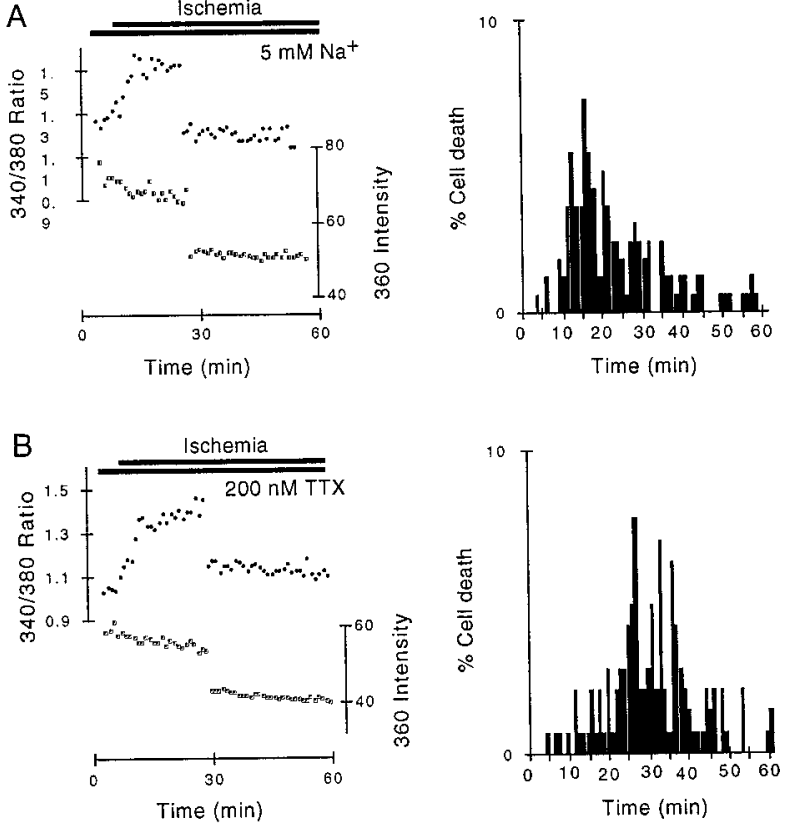

Figure 4. $\mathrm{Na}^{+}$influx was not important in rapid ischemic cell death of cultured immature oligodendrocytes. $A$, A typical response to ischemia during perfusion with aCSF that contained only $5 \mathrm{mM} \mathrm{Na}^{+}(128 \mathrm{mM}$ choline) is shown. Left, Significant increases in $\left[\mathrm{Ca}^{2+}\right]_{i}$ were associated with cell death. B, Left, During perfusion with $200 \mathrm{nM}$ TTX a typical response involved a rapid increase in $\left[\mathrm{Ca}^{2+}\right]_{\mathrm{i}}$ and subsequent cell death. $A, B$, Right, The distribution of cell death is plotted.

mounted in the microscope, the number of cells on the coverslip was counted by eye (there were $4-20$ cells/coverslip), and a cell distant from other cells was chosen for study. Typically, the cell closest to the chamber inflow was selected, and in all cases only one cell was present within the visual field of the microscope (a $100 \mu \mathrm{m}^{2}$ area). Typical effects of ischemia on these very lowdensity immature oligodendrocytes are shown in Figure 8. Cell
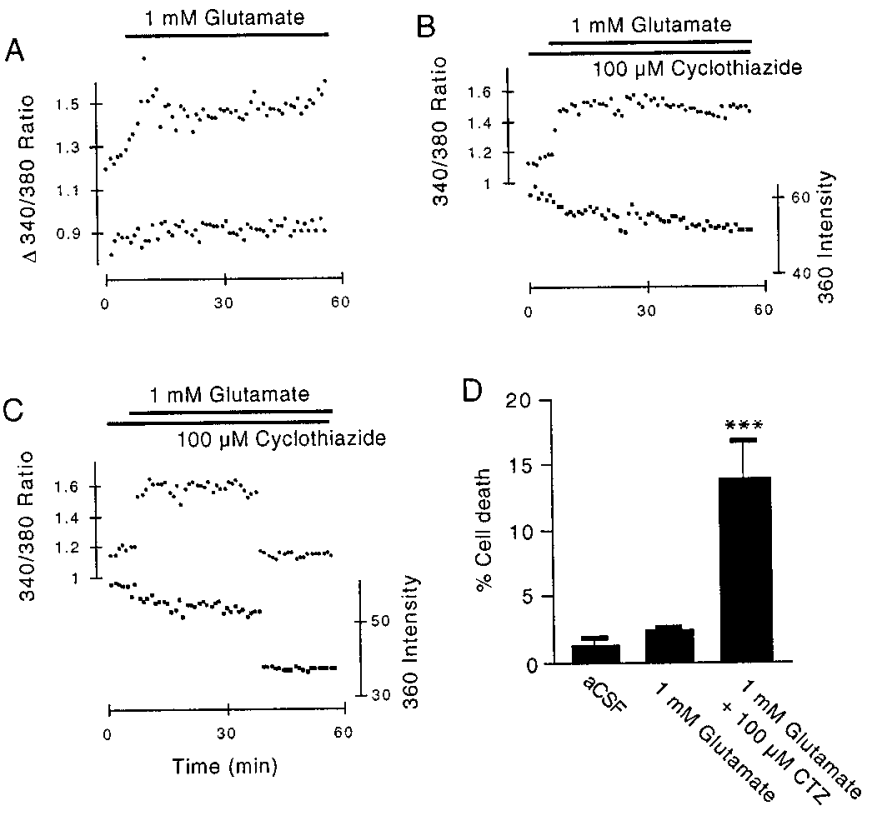

Figure 5. The effects of perfusion with glutamate on immature oligodendrocytes. $A$, Application of $1 \mathrm{~mm}$ glutamate produced either a partially desensitizing response (top data points) or no significant response (bottom data points). Plots have been arbitrarily shifted along the $y$-axis for clarity. $B$, In the presence of the non-NMDA glutamate receptor desensitization blocker cyclothiazide $(100 \mu \mathrm{M})$, perfusion with $1 \mathrm{~mm}$ glutamate produced a sustained increase in $\left[\mathrm{Ca}^{2+}\right]_{i}$, which in this case was not associated with cell death as demonstrated by the stable 360 signal. $C$, A cell that died during perfusion with $1 \mathrm{~mm}$ glutamate in the presence of cyclothiazide is shown. $D$, The extent of cell death over $55 \mathrm{~min}$ in the presence of $1 \mathrm{~mm}$ glutamate and $1 \mathrm{~mm}$ glutamate $+100 \mu \mathrm{M}$ cyclothiazide $(C T Z)$ is shown.

death occurred in 6 out of 12 of the cells (Fig. $8 \mathrm{~A}$, arrow), and ischemia was followed by an increase in $\left[\mathrm{Ca}^{2+}\right]_{\mathrm{i}}$ in all 12 cells including cells that survived (Fig. $8 B$ ). The mean time to cell death was $40.1 \pm 1.0 \mathrm{~min}$, significantly longer than in normal cultures $(p<0.001)$. 
A

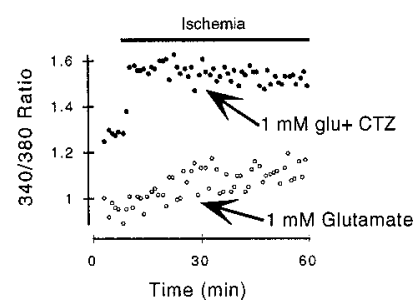

B

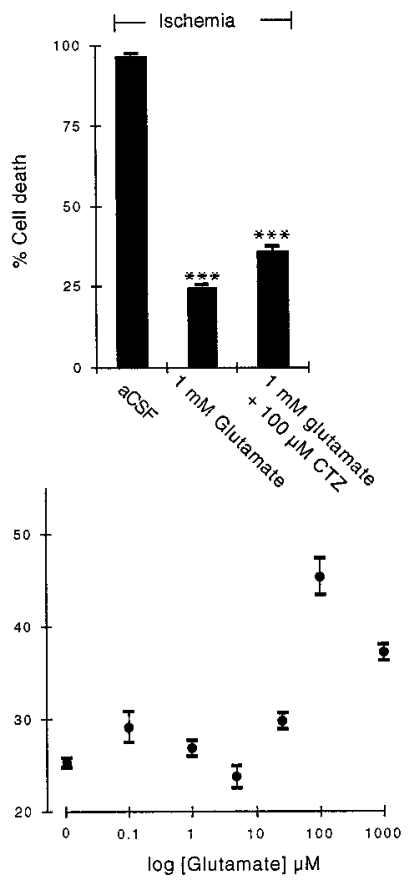

Figure 6. High extracellular glutamate is protective against ischemic injury. $A$, In the presence of $1 \mathrm{~mm}$ glutamate, ischemia typically produced only a small gradual increase in $\left[\mathrm{Ca}^{2+}\right]_{\mathrm{i}}$ (bottom data points, open circles). This effect of $1 \mathrm{~mm}$ glutamate $(\mathrm{glu})$ on ischemic $\left[\mathrm{Ca}^{2+}\right]_{\mathrm{i}}$ changes was removed by cyclothiazide (top data points, filled circles). B, The data summary shows that $1 \mathrm{~mm}$ glutamate was significantly protective against ischemic cell death, an effect significantly reduced by $100 \mu \mathrm{M} C T Z$ (see text). $C$, The dose dependence of the protective effect of glutamate against ischemic cell death is shown. The extent of cell death was significantly reduced by $100 \mu \mathrm{M}$ and $1 \mathrm{~mm}$ glutamate. $D$, The mean time to cell death was also extended by these high concentrations of glutamate.

\section{Mature oligodendrocytes}

The $\mathrm{O}^{+} / \mathrm{GC}^{-}$immature oligodendrocytes that are used in this study and that populate fetal white matter have a number of physiological differences from the more mature oligodendrocytes used in some previous studies (Matute, 1998; McDonald et al., 1998). To test the sensitivity to ischemic injury in more mature oligodendrocytes, cells remained in primary culture for 30-60 d before plating onto coverslips. These cells had more extensive processes than the immature cells and were $\mathrm{A}_{2} \mathrm{~B}_{5}{ }^{-} / \mathrm{GC}^{+}$(Fig. $9 C$, inset). Fifty-five minutes of ischemia produced either no change in $\left[\mathrm{Ca}^{2+}\right]_{\mathrm{i}}$ in these cells or a gradual increase (Fig. $9 A, B$ ). Only $43.4 \pm 5.3 \%$ of the mature cells died during this length of ischemia $(n=138)$, with a mean time to death of $42.8 \pm 0.8 \mathrm{~min}$. Both the mean time to death and the percentage of cells dying were significantly different from that found in immature oligodendroyctes ( $p<0.001$ in both cases). A comparison of the distribution of cell death with that of immature cells is shown in Figure $9 C$.

\section{DISCUSSION}

The current study focused on acute ischemic injury in cultured immature oligodendrocytes (almost all $\mathrm{O}^{+} / \mathrm{GC}^{-}$and a large proportion also $\mathrm{A}_{2} \mathrm{~B}_{5}{ }^{+} / \mathrm{GC}^{-}$). These cells correspond closely to the immature oligodendrocytes that populate CNS white matter at the start of the process of myelination, a developmental period highly vulnerable to periventricular leukomalacia (Back et al., 1998) (see introductory remarks). The onset of ischemia was followed in these cells by an increase in $\left[\mathrm{Ca}^{2+}\right]_{\mathrm{i}}$ that resulted primarily from $\mathrm{Ca}^{2+}$ influx through non-NMDA glutamate receptors. The $\left[\mathrm{Ca}^{2+}\right]_{\mathrm{i}}$ increase was apparent within $1 \mathrm{~min}$ of the onset of ischemia in most cells and continued to increase for 5-10 min before reaching a plateau. Cell death became evident within 5 min of the onset of ischemia, and the mean time to cell death was 20.4 min with $80 \%$ of the cells dead after $31 \mathrm{~min}$; this represents the highest sensitivity to ischemic injury in any CNS cell type yet studied (Petito and Pulsinelli, 1984; Goldberg and Choi, 1993; Johnson et al., 1994; Pantoni et al., 1996; Kusumoto et al., 1997; Lyons and Kettenmann, 1998; Petito et al., 1998).

The rapid onset of cell death was a product of $\mathrm{Ca}^{2+}$ influx because no significant cell death occurred in the absence of extracellular $\mathrm{Ca}^{2+}$ or when non-NMDA glutamate receptors were blocked with CNQX. Block of other potential sources of $\mathrm{Ca}^{2+}$ influx such as the $\mathrm{Na}^{+}-\mathrm{Ca}^{2+}$ exchanger or voltage-gated $\mathrm{Ca}^{2+}$ channels did not reduce the extent of cell death during ischemia or increase significantly the time to death. The mechanism of $\mathrm{Ca}^{2+}$ influx and cell death in immature oligodendrocytes is therefore distinct from that found in astrocytes (Fern, 1998, 2000), neurons (Goldberg and Choi, 1993), or axons (Stys, 1998) and was similar, although far more rapid, than that reported in mature oligodendrocytes (Yoshioka et al., 1996; Matute, 1998; McDonald et al., 1998). The mechanism of cell death of immature oligodendroyctes is summarized in Figure 10.

Although cell swelling has been observed in mature oligodendrocytes during ischemia (Pantoni et al., 1996; McDonald et al., 1998), there was no systematic change in the 360 intensity (the isosbestic point of fura-2) recorded from cells during ischemia in the current experiments. Any net increase in the water content of the cells associated with swelling would lead to dye dilution and reduction in the 360 intensity (see Fern, 1998). Lowering the extracellular $\mathrm{Na}^{+}$concentration, which will reduce $\mathrm{Na}^{+}$dependent cell swelling (Goldberg and Choi, 1993), did not affect the extent or time course of cell death during ischemia. These data indicate that cell swelling is not an important factor in the rapid ischemic cell death of immature oligodendrocytes reported here.

\section{Glutamate release}

The protective action of glutamate receptor block and of a glutamate-scavenging system confirmed the role of extracellular glutamate in ischemic cell death of immature oligodendrocytes. Contaminating cell types were extremely rare in the cell cultures, and the source of glutamate in the bath during ischemia is therefore the oligodendrocytes themselves. Oligodendrocytes express functional glutamate transporters including GLAST and GLT-1 (Reynolds and Herschkowitz, 1986; Kondo et al., 1995; Domercq and Matute, 1999), which will operate in glutamate release mode under ischemic conditions (Nicholls and Attwell, 1991; Levi and Raiteri, 1993). The protective action of the reverse glutamate transport inhibitor DKA (Seki et al., 1999) confirmed that reverse glutamate transport was the mechanism of glutamate release during ischemia. Perfusion with $\mathrm{Na}^{+}$-depleted aCSF or with the voltage-gated $\mathrm{Na}^{+}$channel blocker TTX was not protective against ischemic injury, indicating that $\mathrm{Na}^{+}$influx is not an important element in reverse glutamate transport in these cells.

\section{Glutamate receptor desensitization}

Rapid desensitization is a feature of non-NMDA glutamate receptors that can limit toxic influx of $\mathrm{Ca}^{2+}$ via this route (David et 
Figure 7. Glutamate receptor activation during ischemia was a product of glutamate release via reverse transport. $A$, In the presence of a glutamatescavenging system (pyruvate + GPT), ischemia typically produced a small increase in $\left[\mathrm{Ca}^{2+}\right]_{\mathrm{i}}$ that resulted in somewhat delayed cell death. $B$, In the presence of pyruvate alone, large increases in $\left[\mathrm{Ca}^{2+}\right]_{\mathrm{i}}$ were found during ischemia that typically result in earlier cell death. $C$, The extent of cell death during ischemia was significantly reduced by perfusion with the glutamate-scavenging system but not with pyruvate alone. $D$, Ischemia during perfusion with the reverse glutamate exchange inhibitor DKA typically produced a slow increase in $\left[\mathrm{Ca}^{2+}\right]_{\mathrm{i}}$ that may be associated with cell death. $E$, The distribution of cell death during ischemia in $100 \mu \mathrm{M}$ DKA (dark bars) compared with that during control ischemia (light bars) is shown.
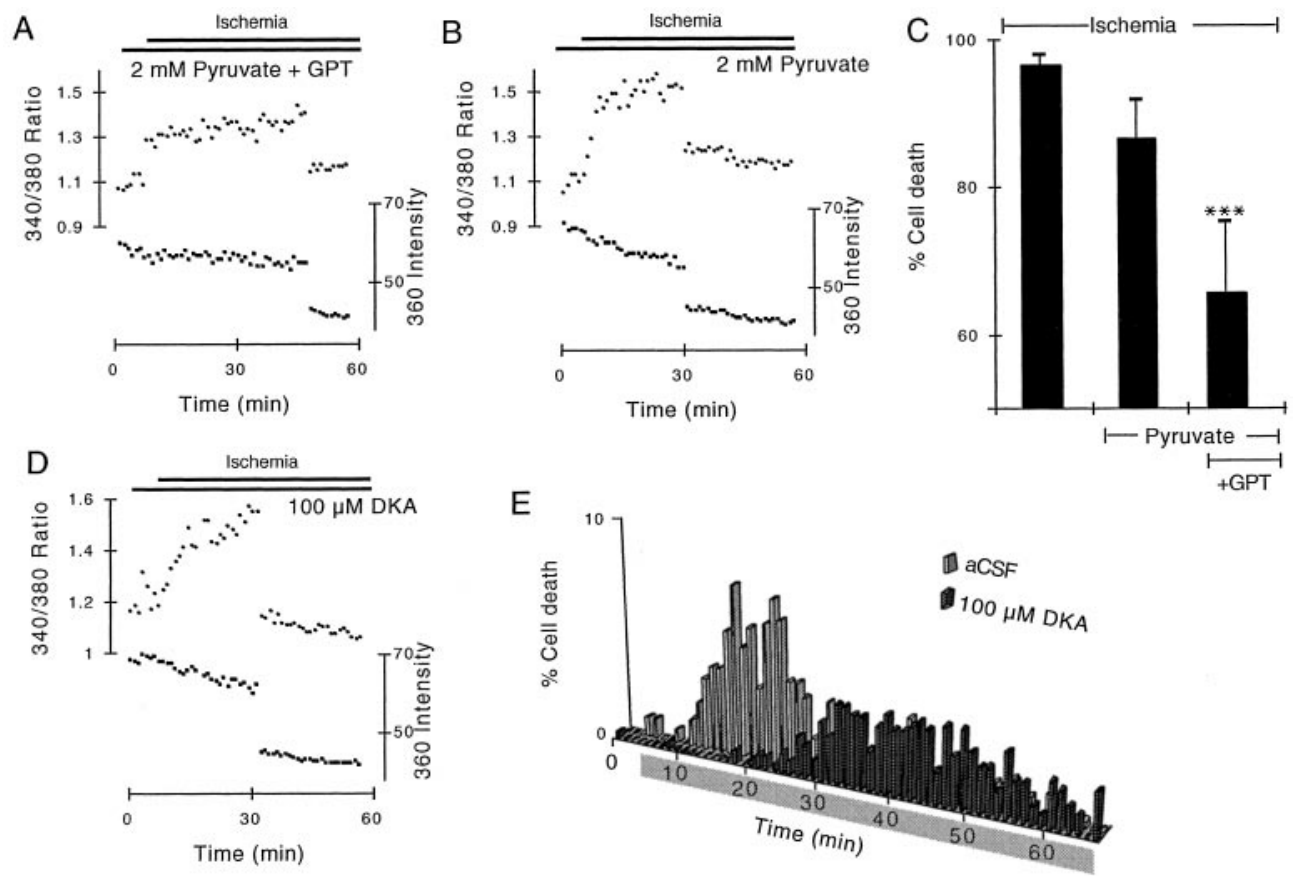

tions would be protective of immature oligodendrocytes during the initial period of an ischemic event in vivo and that the precise extracellular glutamate concentration present during the development of periventricular leukomalacia will be a critical variable for oligodendrocyte survival.

\section{Fatal autologous glutamate feedback?}

The observation that glutamate release from immature oligodendrocytes is fatal to these cells raises the possibility of autologous feedback, i.e., glutamate released from a cell acting on receptors on the same cell. When cells were plated on coverslips at very low density, ischemia was followed by an increase in $\left[\mathrm{Ca}^{2+}\right]_{i}$ in all cells, resulting in cell death within $55 \mathrm{~min}$ in $50 \%$ of cells. Because only one cell was visible in the microscope field (100 $\mu \mathrm{m}^{2}$ ) the minimum distance over which glutamate would have to diff use from a neighboring cell under these conditions is $50 \mu \mathrm{m}$. In some coverslips as few as four cells were counted on the entire coverslip, representing a much larger cell-free zone around the cell under study. In all cases, a cell at the chamber inlet edge of the coverslip was selected, so that contaminating glutamate from neighboring cells would have to diff use against the fluid flow to reach the cell being studied. These considerations strongly indicate that glutamate released during ischemia acted on glutamate receptors on the homologous cell to evoke potentially fatal $\mathrm{Ca}^{2+}$ influx. In vivo, where the extracellular space around cells is limited (Nicholson and Sykova, 1998), conditions will strongly favor the operation of a similar autologous feedback loop mediated by the glutamate transport proteins known to be present on these cells in situ (Domercq and Matute, 1999).

\section{Extremely rapid ischemic injury}

The time course of immature oligodendrocyte death during ischemia reported here is rapid. Previous studies have shown that early injury to oligodendrocytes is a feature of ischemic adult brain in vivo (Pantoni et al., 1996; Petito et al., 1998). In the current study, ischemic injury of mature $\left(\mathrm{GC}^{+}\right)$oligodendrocytes occurred more slowly than that of immature oligodendrocytes, at a rate similar to that reported previously for non-NMDA ated by a separate, more slowly operating, pathway. The current findings suggest that very high extracellular glutamate concentra- 

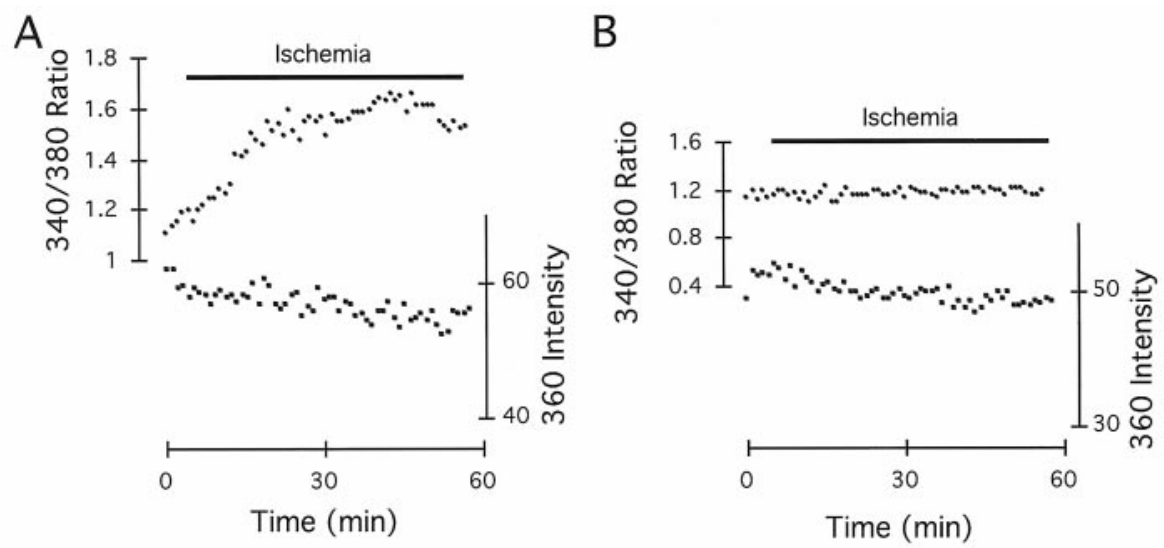

C

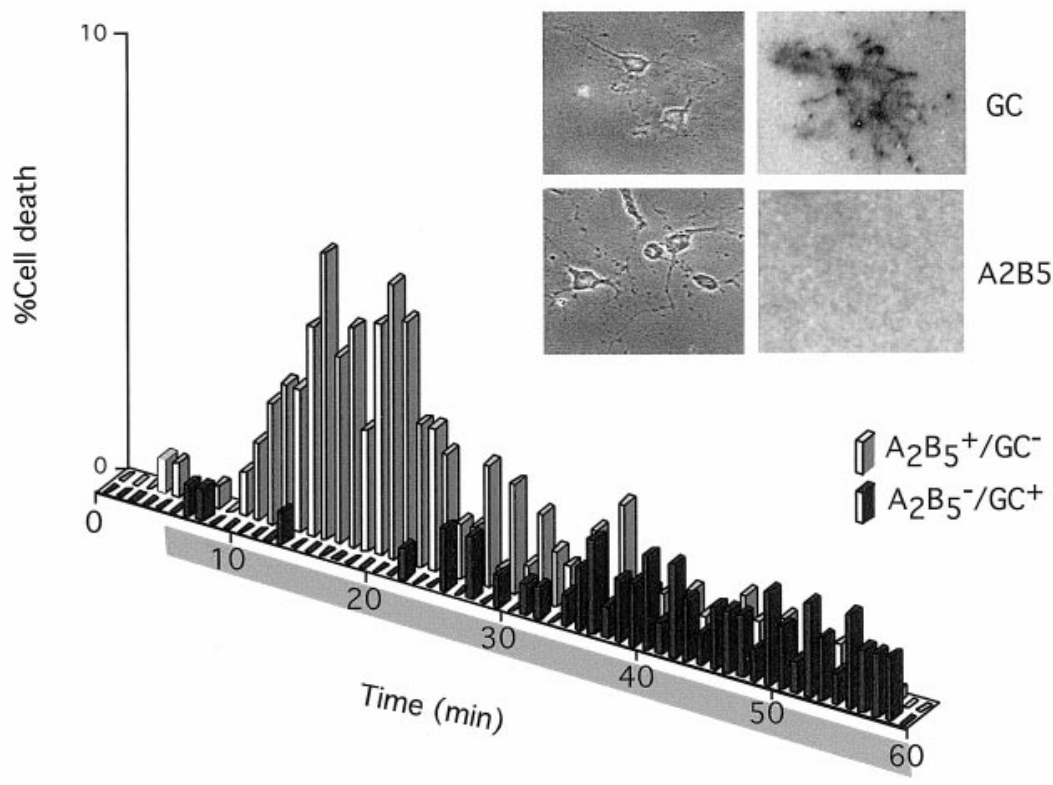

Figure 9. Mature $\left(\mathrm{A}_{2} \mathrm{~B}_{5}{ }^{-} / \mathrm{GC}^{+}\right)$oligodendrocytes were more resistant to ischemic injury than were immature $\left(\mathrm{O}^{+} / \mathrm{GC}^{-}\right)$oligodendrocytes. $A$, Slow changes in $\left[\mathrm{Ca}^{2+}\right]_{i}$ followed the onset of ischemia in cells remaining in primary culture for $30-60 \mathrm{~d}$ before plating. $B$, Some cells showed no significant change in $\left[\mathrm{Ca}^{2+}\right]_{\mathrm{i}}$ during ischemia. $C, \mathrm{~A}$ comparison of the distribution of cell death during ischemia in immature (gray bars) and mature (black bars) oligodendrocytes is shown. Inset, Phase-contrast images of mature cells are shown on the left, and GC (top) and $\mathrm{A}_{2} \mathrm{~B}_{5}{ }^{-}$(bottom) immunoreactivity is shown on the right. Note that cells are $\mathrm{A}_{2} \mathrm{~B}_{5}{ }^{-} / \mathrm{GC}^{+}$. receptor-mediated injury of $\mathrm{GC}^{+}$oligodendrocytes $(\mathrm{McD}$ onald et al., 1998) and mature oligodendrocytes during ischemia in vivo (Pantoni et al., 1996; Petito et al., 1998). The time course of oligodendrocyte injury in ischemic CNS white matter during the

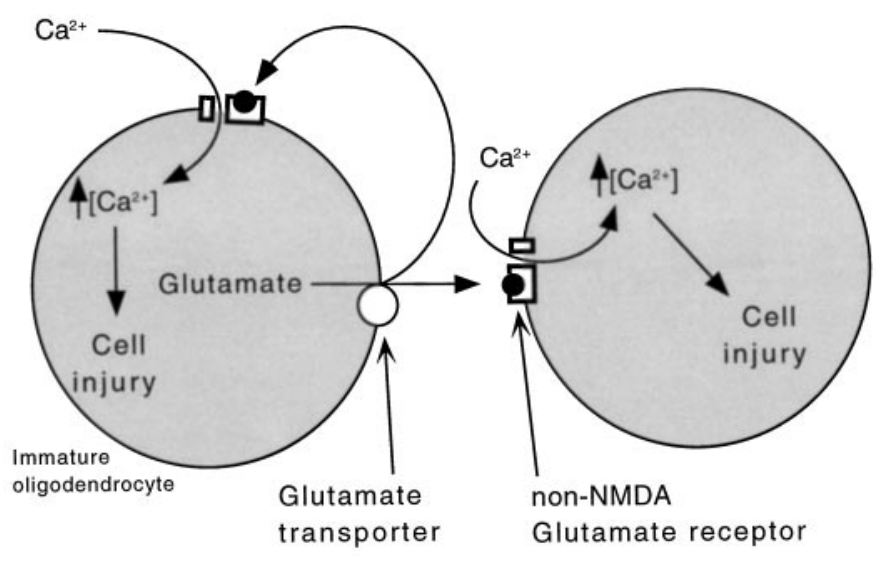

Figure 10. A model of ischemic cell death in immature oligodendrocytes. Ischemia leads to the release of glutamate from cells via reverse transport. The buildup of extracellular glutamate resulted in the gating of $\mathrm{Ca}^{2+}$ permeable non-NMDA glutamate receptors resulting in the influx of $\mathrm{Ca}^{2+}$ and cell death, with some glutamate feeding back on the cell that released it. development of periventricular leukomalacia is not known, but the current results indicate a critical sensitivity to ischemia in cultured cells at the same developmental point. This suggests that pharmacological intervention to protect immature oligodendrocytes in the fetus at risk of cerebral palsy is an area worthy of future investigation because injury to these cells may be the earliest cellular manifestation of coagulating necrosis.

\section{REFERENCES}

Back SA, Gan X, Li Y, Rosenberg PA, Volpe JJ (1998) Maturationdependent vulnerability of oligodendrocytes to oxidative stress-induced death caused by glutathione depletion. J Neurosci 18:6241-6253.

Banker BQ, Larroche J-C (1962) Periventricular leukomalacia of infancy: a form of neonatal noxic encephalopathy. Arch Neurol 7:386-410.

Bevensee MO, Schwiening CJ, Boron WF (1995) Use of BCECF and propidium iodide to assess membrane integrity of acutely isolated CA1 neurons from rat hippocampus. J Neurosci Methods 58:61-75.

David JC, Yamada KA, Bagwe MR, Goldberg MP (1996) AMPA receptor activation is rapidly toxic to cortical astrocytes when desensitization is blocked. J Neurosci 16:200-209.

Domercq W, Matute C (1999) Expression of glutamate transporters in the adult bovine corpus callosum. Mol Brain Res 67:296-302.

Fern R (1998) Intracellular calcium and cell death during ischemia in neonatal rat white matter astrocytes in situ. J Neurosci 18:7232-7243.

Fern R (2000) Ischemia, astrocytes, and the aging brain. In: Neuroglia and the aging brain (deVellis J, ed). Humana, in press.

Flodmark O, Lupton B, Li D, Stimac GK, Roland EH, Hill A (1989) 
MR imaging of periventricular leukomalacia in childhood. AJR Am J Roentgenol 152:583-590.

Geeraerts MD, Ronveaux-Dupal MF, Lemasters JJ, Herman B (1991) Cytosolic free $\mathrm{Ca} 2+$ and proteolysis in lethal oxidative injury in endothelial cells. Am J Physiol 261:C889-C896.

Goldberg MP, Choi DW (1993) Combined oxygen and glucose deprivation in cortical cell culture: calcium-dependent and calciumindependent mechanisms of neuronal injury. J Neurosci 13:3510-3524.

Grynkiewicz G, Poenie M, Tsien RY (1985) A new generation of Ca2+ indicators with greatly improved fluorescence properties. J Biol Chem 260:3440-3450.

Hardy R, Reynolds R (1991) Proliferation and differentiation potential of rat forebrain oligodendroglial progenitors both in vitro and in vivo. Development 111:1061-1080.

Johnson ME, Gores GJ, Uhl CB, Sill JC (1994) Cytosolic free calcium and cell death during metabolic inhibition in a neuronal cell line. J Neurosci 14:4040-4049.

Kinney HC, Back SA (1999) Human oligodendroglial development: relationship to periventricular leukomalacia. Semin Pediatr Neurol 5:180-189.

Kondo K, Hashimoto H, Kitanaka J, Sawada M, Suzumura A, Marunouchi T, et al. (1995) Expression of glutamate transporters in cultured glial cells. Neurosci Lett 188:140-142.

Kuban KC, Leviton A (1994) Cerebral palsy [see comments]. N Engl J Med 330:188-195.

Kusumoto M, Dux E, Hossmann KA (1997) Effect of trophic factors on delayed neuronal death induced by in vitro ischemia in cultivated hippocampal and cortical neurons. Metab Brain Dis 12:113-120.

Lemasters JJ, DiGuiseppi J, Nieminen AL, Herman B (1987) Blebbing, free $\mathrm{Ca} 2+$ and mitochondrial membrane potential preceding cell death in hepatocytes. Nature 325:78-81.

Levi G, Raiteri M (1993) Carrier-mediated release of neurotransmitters. Trends Neurosci 16:415-419.

Leviton A, Paneth N (1990) White matter damage in preterm newborns - an epidemiologic perspective [review]. Early Hum Dev 24:1-22.

Lyons SA, Kettenmann H (1998) Oligodendrocytes and microglia are selectively vulnerable to combined hypoxia and hypoglycemia injury in vitro. J Cereb Blood Flow Metab 18:521-530.

Matute C (1998) Characteristics of acute and chronic kainate excitotoxic damage to the optic nerve. Proc Natl Acad Sci USA 95:10229-10234.

Matute C, Sanchez-Gomez MV, Martinez-Millan L, Miledi R (1997) Glutamate receptor-mediated toxicity in optic nerve oligodendrocytes. Proc Natl Acad Sci USA 94:8830-8835.

McCarthy KD, de Vellis J (1980) Preparation of separate astroglial and oligodendroglial cell cultures from rat cerebral tissue. J Cell Biol 85:890-902.

McDonald JW, Althomsons SP, Hyrc KL, Choi DW, Goldberg MP (1998) Oligodendrocytes from forebrain are highly vulnerable to AMPA/kainate receptor-mediated excitotoxicity. Nat Med 4:291-297.

Miller RH (1996) Oligodendrocyte origins. Trends Neurosci 19:92-96.

Min MY, Rusakov DA, Kullmann DM (1998) Activation of AMPA, kainate, and metabotropic receptors at hippocampal mossy fiber synapses: role of glutamate diffusion. Neuron 21:561-570.
Nicholls D, Attwell D (1991) The release and uptake of excitatory amino acids. Trends Pharmacol Sci 13:68-74.

Nicholson C, Sykova E (1998) Extracellular space structure revealed by diff usion analysis. Trends Neurosci 21:207-215.

O'Brien RJ, Fischbach GD (1986) Modulation of embryonic chick motoneuron glutamate sensitivity by interneurons and agonists. J Neurosci 6:3290-3296.

Oka A, Belliveau MJ, Rosenberg PA, Volpe JJ (1993) Vulnerability of oligodendroglia to glutamate: pharmacology, mechanisms, and prevention. J Neurosci 13:1441-1453.

Paneth N, Rudelli R, Kazam E, Monte W (1994) Brain damage in the preterm infant. Cambridge, United Kingdom: Cambridge UP.

Pantoni L, Garcia JH, Gutierrez JA (1996) Cerebral white matter is highly vulnerable to ischemia. Stroke 27:1641-1644, 1647.

Patneau DK, Vyklicky Jr L, Mayer ML (1993) Hippocampal neurons exhibit cyclothiazide-sensitive rapidly desensitizing responses to kainate. J Neurosci 13:3496-3509.

Petito CK, Pulsinelli WA (1984) Sequential development of reversible and irreversible neuronal damage following cerebral ischemia. J Neuropathol Exp Neurol 43:141-153.

Petito CK, Olarte JP, Roberts B, Nowak Jr TS, Pulsinelli WA (1998) Selective glial vulnerability following transient global ischemia in rat brain. J Neuropathol Exp Neurol 57:231-238.

Reynolds R, Herschkowitz N (1986) Selective uptake of neuroactive amino acids by both oligodendrocytes and astrocytes in primary disassociated culture: a possible role for oligodendrocytes in neurotransmitter metabolism. Brain Res 371:253-266.

Rice JE, Vannucci RC, Brierley JB (1981) The influence of immaturity on hypoxic-ischemic brain damage in the rat. Ann Neurol 9:131-141.

Rivkin MJ, Flax J, Mozell R, Osathanondh R, Volpe JJ, Villa Komaroff L (1995) Oligodendroglial development in human fetal cerebrum. Ann Neurol 38:92-101.

Rorke LB (1992) Perinatal brain damage. In: Greenfield's neuropathology (Adams JH, Duchen LW, eds), pp 639-709. London: Arnold.

Seki Y, Feustel PJ, Keller Jr RW, Tranmer BI, Kimelberg HK (1999) Inhibition of ischemia-induced glutamate release in rat striatum by dihydrokainate and an anion channel blocker. Stroke 30:433-440.

Sommer I, Schachner M (1981) Monoclonal antibodies (O1 to O4) to oligodendrocyte cell surfaces: an immunocytological study in the central nervous system. Dev Biol 83:311-327.

Stys PK (1998) Anoxic and ischemic injury of myelinated axons in CNS white matter: from mechanistic concepts to therapeutics. J Cereb Blood Flow Metab 18:2-25.

van de Bor M, Guit GL, Schreuder AM, Wondergem J, Vielvoye GJ (1989) Early detection of delayed myelination in preterm infants. Pediatrics 84:407-411.

Volpe JJ (1995) Neurology of the newborn. Philadelphia: Saunders.

Yamada KA, Tang CM (1993) Benzothiadiazides inhibit rapid glutamate receptor desensitization and enhance glutamatergic synaptic currents. J Neurosci 13:3904-3915.

Yoshioka A, Bacskai B, Pleasure D (1996) Pathophysiology of oligodendroglial excitotoxicity. J Neurosci Res 46:427-437. 